\title{
Bulk store as an effort to reduce marine debris in Bajo Pulau
}

\author{
Aziz Ali Haerulloh ${ }^{*}$; Hazman Hiwari ${ }^{2}$ \\ ${ }^{1)}$ History and Philology Department, Faculty of Cultural Sciences, Universitas \\ Padjadjaran, Indonesia \\ ${ }^{2)}$ Marine Science Department, Faculty of Fisheries and Marine Sciences, Universitas \\ Padjadjaran, Indonesia
}

*To whom correspondence should be addressed.Email: aziz.alihaerulloh30@gmail.com

\begin{tabular}{|l|l|l|l|l|}
\hline DOI: & Received: & Revised: & Accepted: & Published: \\
$10.22437 /$ ppd.v8i5.10708 & 14.12 .2019 & 27.09 .2020 & 12.12 .2020 & 31.12 .2020 \\
\hline
\end{tabular}

\begin{abstract}
Damage to coastal ecosystems and shallow waters of the Bajo Pulau Village, Sape Subdistrict, Bima District, West Nusa Tenggara Province is caused by the accumulation of household waste that is not managed by the community from year to year. It resulted in a reduction in the quality of seawater. This study examines the various factors behind it and synthesizes the solution to the problem by proposing a bulk store. The research method used is descriptive-analytic with a qualitative approach. Data collection was carried out by observation, field studies, literature studies, and interviews. The results showed that Indonesia (as the largest archipelagic country) has a low interconnectivity level. It causes small islands to be vulnerable to environmental degradation. This vulnerability is also caused by the lack of a business system that considers sustainable environmental capabilities. Therefore, it is necessary to reduce the amount of household waste scattered on land and in the sea that threatens the surrounding ecosystem with the concept of a minimal garbage collection facility based on a cooperative system.
\end{abstract}

Keywords: Bulk store, Cooperative, Consumerism, Pollution, Waterfront city

JEL Classsification: Q22, Q25, Q26

\section{INTRODUCTION}

The waste problem is a significant problem that Indonesia is currently facing, particularly the contamination of waste in the sea. Long ago in the archipelago, which now occupies the Republic of Indonesia's territory, people have the slogan 'Jales Viva Jayamahe' ('in our glorious sea'). However, this phrase is less applicable to the problems currently facing Indonesia (Zuhdi, 2006). It has been estimated that 150 million tons of plastic waste are in the oceans of the world. This will continue to increase to 250 million tons of production, consumption, and urbanization continue. As much as $50 \%$ of the waste in the ocean is the responsibility of 5 of the 192 largest waste producer countries, one of which is Indonesia. Indonesia has a strategic position between the continents of Asia and Australia and the Indian and Pacific Oceans (Joesoef, 2014: 83). The source of waste entering the ocean comes from human activities (Cozar et al., 2014). This is inseparable from the three factors that cause the waste problem, including a culture of consumerism. This business structure does not pay attention to the carrying capacity of a sustainable environment. It does not optimally apply the definition of a waterfront city, especially in Indonesia, as the world's largest archipelago country (Burhanuddin, 2017). 
Consumerism, in economic terms, was born out of a deviation in the orientation of consumption practices. According to (Hasan, 2018), consumption is a practice that often tries to achieve the highest degree of satisfaction in consumption activities. Acknowledging the habits of the Indonesian people from year to year continues to show negative patterns, particularly in daily consumption, resulting in large household waste.

Indonesia's consumer culture has culminated in Indonesia being the world's secondlargest contributor to marine debris, amounting to 3.2 million tons (Purba, 2017). Besides, certain forms of waste generated cannot be degraded within a relatively short period. Based on the study results, at least inorganic waste (plastic, cigarette butts, and soft drink cans) will take about 50-100, 10, and 80-100 years (Petungsewu Wildlife Education Center, 2019). This phenomenon will continue to occur if the Indonesian Government does not take preventive steps to reduce household waste's "production" by promoting changes in people's habits comprehensively and continuously.

According to Dahuri, Rais, Sapta, and Sitepu (2001), as cited by Efendy (2009), almost 65 percent of Indonesia's population resides in coastal and marine areas. The situation is getting worse due to the high culture of consumerism in Indonesia, especially in coastal areas that affect environmental pollution that has already been stated. This is attributable to the insufficient implementation of the definition of the waterfront city in Indonesia. According to (Munandar, 2013), the waterfront city is a definition of settlement growth facing the sea or river to enhance and coordinate the area's quality. In general, the waterfront city model's implementation is supposed to address pollution, environmental instability, and waste (Annisa, 2016).

The idea of a low-waste shop has been adapted from a bulk store that is well known to international cultures such as Germany, Canada, Singapore, and the Netherlands (Bahagijo, 2019). Bulk stores are unique compared to mini markets, supermarkets, hypermarkets, department stores, and wholesalers that we may find in various regions. The minimum waste shop is a business enterprise that regularly serves the city's diverse needs by applying the zero waste principle. In this report, the idea of a minimal waste shop will have cooperated with a cooperative business structure that opens up opportunities for local community involvement to enhance collective welfare while reducing environmental emissions due to waste and household waste.

This research is located in Bajo Pulau, Sub-district of Sape, District of Bima, Province of West Nusa Tenggara (NTB). Bajo Pulau is a coastal village. Based on Village Potential data or Potensi Desa (PODES), out of 82,190 villages, 12,827 villages, or around 15,61 percent, were coastal villages (Badan Pusat Statistik, 2016).

This study aims to analyze: 1) the causes of environmental degradation in Bajo Pulau Village, 2) the impact of the culture of consumerism in Bajo Pulau Village on the sustainability of the marine ecosystem, 3) the idea of bulk storage as an attempt to minimize marine pollution in the Bajo Pulau Village.

Several previous studies related to marine water contamination analysis due to lifestyle and environmental protection policies have not been carried out optimally and comprehensively. For example, the National Development Planning Agency (2017) discussed maritime development policies in Indonesia's realization as the world maritime axis region. Other research explored cooperatives, waste concerns, and consumerism as the key topics for a maritime country such as Indonesia. State of the marine crisis (Greenpeace, $\mathrm{tt}$ ), sea, rivers and society creation (Zuhdi, 2006), marine debris (Purba, 2017), marine waste management (Burhanuddin, 2017), human economic empowerment cooperatives (Mulyono, 2010), use of space in the waterfront (Annisa, 2016), a marine waste irony in maritime countries (Purba, 2016), the status of marine debris (Purba, 2017). 


\section{METHODS}

This research was conducted in Bajo Pulau Village, Sape Sub-district, Bima District, Tenggara Province, West Nusa. The region that will become the subject of this research study is located in Bajo Pulau Village, classified as 3T (Tertinggal, Terdepan, and Terluar) or Left Behind, Frontier Outermost in Indonesia.

The data collection method used was purposive sampling with the residents of West and Central Bajo and Pasir Putih's hamlets as samples. The total number of heads of households in the three hamlets is 533. Samples from the three hamlets were each taken by one respondent, that is, the residents who own houses by the sea. The data was then processed into a transcript of the results of the interview.

This study used a qualitative approach to analyze observations, interviews, field studies, literature studies, and numerous other online sources. The data analysis approach used is descriptive and analytical. According to (Sugiyono, 2003) in (Sulipan, t.t), descriptive is a method used to identify the value of an independent variable, either one or more (independent variables without making comparisons or comparing one variable to another. Analytical is an attempt to explain what has been described in an investigative, subtle, in-depth, systematic, and reasonable manner to know the cause and effect.

\section{RESULT AND DISCUSSION}

\section{Condition of territory and community of Bajo Pulau Village}

Bajo Pulau Village is two small, populated islands not far from Sape Harbor, Bima Regency. Sape Harbor is about 45 kilometers east of Bima City. Bajo Pulau Village is divided into three hamlets, West and Central Bajo Hamlets on Bajo Island (Nisa) and Pasir Putih Hamlet on Nae Island (Nisa).

Bajo Pulau Village inhabitants are socially divided into several community units or rukun warga (RW) and neighborhood units or rukun tetangga (RT). Influential local community leaders usually hold each head of RW and RT. Punggawa is another name for chief of the Bajo ethnicity (Kurais, 2016). In their religious and cultural life, the Bajo Pulau Village people are considered to be religious. They conserve some of their ancestral cultural heritage, which is still important to live in today. Bajo Pulau Village contains a wide variety of potential biological resources and natural ecosystems, such as coral reefs still in good condition (Ekspedisi Nusantara Jaya Unpad, 2018).

There are several remote areas in Indonesia. One of them is Bajo Pulau Village, which is a small island area. These areas require infrastructure development that is more suitable and in line with the needs of the local population, such as cold storage, health centers, education (secondary and vocational), literacy (village libraries), information (cellular networks), and culture (Magdoff and Foster, 2018: x). Bajo Pulau Village is one of the villages in Sape District where most of the population is ethnic Bajo (sea tribe). The socio-economic conditions in Bajo Pulau are generally lower-middle-income people, with the majority of the community being fishermen. Apart from being a fisherman, many people have dual careers as a sea bike taxi, a transport word that links the Bajo Pulau Village to the Sape District (Sudirman, 2018). Another very striking feature of the settlement of the Bajo Tribe is its position on the coast or in coral clusters (Baskara, 2011).

Grouper and lobster are the two most valuable commodities for the people of Bajo Pulau Village. However, currently, it is increasingly difficult to obtain these two commodities in Bajo Pulau Village's waters. This is due to the damage to the marine ecology due to household waste polluting the sea and the massive use of fishers' fish bombs. Therefore, people have started to cultivate these two commodities. At this time, many people become entrepreneurs by making grouper and lobster cages in the waters around the settlements (Mustikari et al., 2019) (Greenpeace, t.t). 
"The record of the reduction of many species of open-sea fish, to the point of near extinction, is an example of how 'renewable resources' can run out. It is estimated that one-third of commercial fishing enterprises can now produce only $10 \% \ldots$ and... almost all species will experience overfishing by the middle of this century (Magdoff \& Foster, 2018: 77)"

The lack of development of fish pond entrepreneurship in Bajo Pulau Village is due to a lack of infrastructure availability. The infrastructure needed by fishermen includes access to clean water, electricity, and large-scale cold storage.

To meet their daily food needs, such as rice, vegetables, and fruit, they rely on the Sape people's crops, who usually work in rice fields and field farmers. Likewise, the Sape people depend on the supply of fish from the catch of Bajo Island people to meet their protein needs. Bajo Pulau Village and Sape District spatially represent a mutually complementary symbiotic relationship.

\section{Consumerism culture in Bajo Pulau Village}

Consumerism is an understanding that promotes a consumptive lifestyle. The motivation of consumer behavior in a traditional economic perspective is related to efforts to achieve self-satisfaction/desire maximization

The culture of consumerism consists of two terms, culture and consumerism. According to Levi Strauss, culture manifests the social system components that originate from the human mind and are replicated in habitual forms. (Maxmanroe, 2019). Consumerism is an understanding that emphasizes a consumptive lifestyle. In a traditional economic perspective, consumer behavior's motivation is related to efforts to achieve selfsatisfaction or desire maximization (Hasan, 2018). The pervasive consumerism culture does not emerge spontaneously and does not exist within the Bajo Pulau Village society. According to Bachtiar (1979), the thoughts we manifest are often not our unique thoughts. Most of our thought consists of cultural elements that we derive from our experiences in culture and education. Many cultural elements have become the regulators of our thought, attitudes, and behavior (Handoyo, Astuti, Iswari, Alimi, \& Mustofa, 2015). Concerning the argument above, culture is typically collective in society.

This consumerism culture is a popular symptom seen in Bajo Pulau Village's everyday lives. This is demonstrated by society's high consumption patterns, particularly in snacks, cigarettes, and packaged beverages (plastic, cans, or glass).

Dozens of stalls may be located next to each other, only in one hamlet. Why do Bajo Pulau Village, a 3T area group, have a consumptive lifestyle? Based on the observations, Bajo Pulau Village citizens or other coastal communities have relatively the same regular period. E.g., men and young men typically go to sea at 17.00/18.00 WITA, while fishing at 18.00-2.00/3.00 WITA in the morning brings food, drinks, and cigarettes.

Most of the supplies are consumables purchased from the Sape Market, which are then resold to the fishermen by stalls in the Bajo Pulau Village. This phenomenon is inspired by a high degree of mobility of fishers and a materialistic mindset since they have a strong entrepreneurial spirit. Besides, they usually enjoy high personal and group prestige (Handoyo, Astuti, Iswari, Alimi, \& Mustofa, 2015). The above behaviors are a factor of support for the consumer nature of coastal communities employed as fishermen. On the other hand, however, carrying packed food from home with their food container to eat and drink has not become a routine for fishers because it is considered impractical and fills the room available on the boat for fish and fishing gear.

"Overconsumption is a lifestyle to consume excessively. In this case, consumption is not always related to food. In the definition of sociology, consumption is the use of something, it can be anything, to satisfy something. Modern humans tend to show 
their social class with the items they consume" (Handoyo, Astuti, Iswari, Alimi, \& Mustofa, 2015).

Things like this also happen to Bajo Pulau Village people, particularly the fishermen who go to sea every day to catch fish sold for export to the fish market in Sape, Lombok or Bali. One of the benchmarks for fishermen's consumption actions as a measure of their social status is the cigarette brand they drink - the more expensive the price, the higher the community's status, and vice versa.

The concept of consumerism culture is like a virus that affects one part of the body and then spreads to other parts of the body. If ignored, causing other parts of the body to be "infected" by consumerism culture. The coastal region's degree of vulnerability varies depending on the intrusion, natural factors, and the effect of human (anthropogenic) behavior (Handiani, Darmawan, Heriati, \& Aditya, 2019). Coastal populations in close interaction with the sea have a major impact on the ecosystem due to their consumptive lifestyle. Of course, this is correlated with the degree of environmental contamination caused by household waste and garbage. Neolaka (2008) analyses a list of lifestyles that affect the environment: (1) a lifestyle that emphasizes enjoyment, leisure, partying; (2) a lifestyle that emphasizes material things; (3) a consumptive lifestyle; and (4) a selfish lifestyle (Handoyo, Astuti, Iswari, Alimi, \& Mustofa, 2015).

Unfortunately, sociologically, living with the opportunity to be over-consuming is a measure of happiness (Handoyo, Astuti, Iswari, Alimi, \& Mustofa, 2015). In many countries, the existence of consumerism is one of the consequences of growth. On this basis, the zero-growth principle was born, a strategy that seeks to be applied worldwide to suppress economic and population growth. This strategy is not very common in developed countries (Rohmad, 2016: 100). More specifically, if the zero-growth hypothesis offered is replaced by balanced growth in an environmentally friendly sustainable development framework. Pollution of the marine environment due to household waste from Bajo Pulau's population, the bulk of the waste is food and beverage packaging.

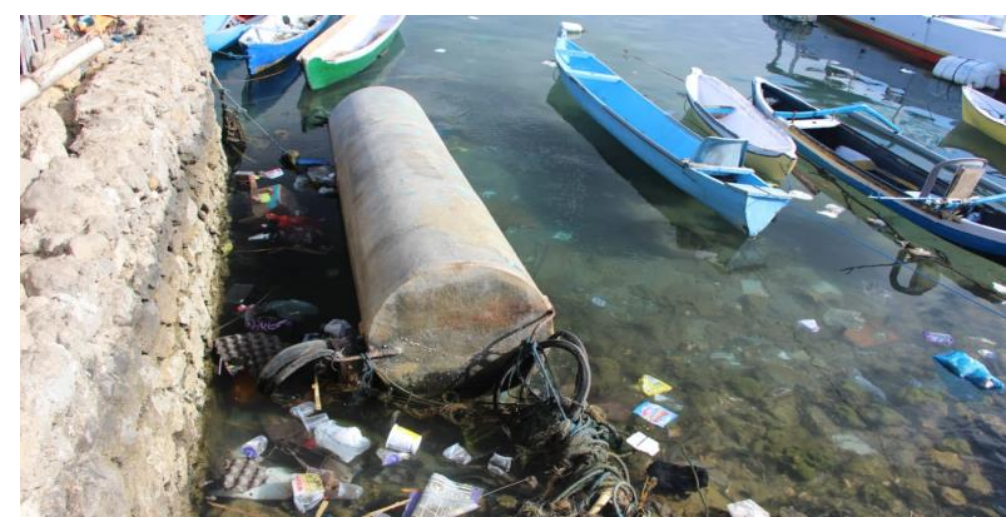

Figure 1. Household trash floating in the West Bajo pier Source: UNPAD ENJ Documentation Team, 2018.

Ernest Collenbach (1999), for healthy living, including waste and garbage. In the old principle, modern people find it cheaper and easier to buy wipes and throw them in the garbage than to use a washable handkerchief. The old law says, "buy cheap and throw away". In the meantime, in the new principle, nothing is necessarily thrown away by the natural principle. We are expected to learn how to emulate nature's values and cycles by recycling everything from plastic, metal, concrete, asphalt, etc. (Handoyo, Astuti, Iswari, Alimi, \& Mustofa, 2015).

The first thing most likely to be done by Bajo Pulau Village citizens is to reject advertising brochures that are not required from many demands to live in an environmentally friendly manner. Second, minimize waste in any manner whatsoever. 
Third, do not purchase or use disposable products. Fourth, the recycling of household waste that can still be used. Various measures can be taken to minimize environmental harm due to waste management that is not optimal and spread consumerism.

The population has not dismissed the ideology of consumerism in the Bajo Pulau Village for any reason whatsoever. High mobility, combined with the open nature of coastal people to society from outside, has bridged the acceptance of this culture to the diverse community of Bajo Pulau. Another reason is inter-regional dependence, which renders the region unable to separate itself to meet its everyday needs (dependency theory) and, on a larger scale, the dependence between the provinces and the state.

\section{The nonoptimal concept of waterfront city in Bajo Pulau}

The development of cities/regions with a waterfront city concept has long been recognized throughout the world as part of a city defined by water boundaries, whether rivers, seas, or lakes (Munandar, 2013). The definition aims to make community settlements near the water (rivers, lakes, and sea) face the house towards the water. The expectation of applying this principle is, connected to most Indonesians' tendency, in general, to the location of their homes facing the rivers and the sea. This definition implies that if community settlements face waterfront areas, it can be ascertained that the majority of the community would not dispose of the residual "production" of their household by river or sea. On the opposite, they can take care of their front yard as best they can, whether it be a river, a lake, or a sea.

Analyzing Lontarak Assalenna Bajo, one of the texts of the Bajo Tribe, the Bajo Tribe established the sea as a place to live (before living permanently) and to make a living. They respect the sea and take good care of it, which is inversely proportional to Bajo Pulau's village's present situation. It is ironic that people throw garbage there carelessly and pay little attention to the sea's health, which is their source of life. A healthy culture must therefore be maintained as mandated by Lontarak Assalena Bajo. The logic of thought needs to be developed since it will direct people to behave as individuals and societies (Riyanto, 2018: 41). Various other archipelago regions in Indonesia, particularly the Bajo Pulau Village, are experiencing the waterfront city's unfavorable concept. The people of Bajo Pulau Village usually have an average elementary school education level. Much lower than the Bima City population, which has a higher average human development index than other central Indonesian provinces. The low education level often affects public understanding of environmental management and sustainable sanitation by paying attention to environmental capacity building.

The issues with the mediocre concept of waterfront cities are industrial waste, livestock waste distribution, household waste, vital property or land-use changes, changes in community habits, reduction of water supplies, and lax law enforcement. However, what is more important is government policies that direct the pattern of settlement development by the principle of maintaining a sustainable environment. Another explanation of why the above definition is not ideal is due to changes in people's perception of nature-Humans position nature as subservient to human life. Society considers nature an object of life that can be 'empowered' to serve human needs without paying attention to aspects of natural law subordinate to nature. In the same way, nature is the master, while humans are servants, what happens today is the reverse. Man is the master, and nature is the worker. There is also an imbalance in the relationship between nature and human beings.

The execution of waterfront city policies is usually the central Government and local governments' outcome, which serve as program implementers. In public policy, it is referred to as recognizing the central government's authority to the regions. However, from a sociological perspective, social change ultimately happens by the social system's 
modifications to changes coming from outside (extra structural change) (Nasikun, 2015). The aims and advantages of a seaside town concept in Bajo Pulau Village have not yet been achieved. However, one day it may be achieved if existing community groups are willing to become active collaborative partners of the central or regional government and non-government organizations (NGOs ) such as Zero Waste Indonesia (ZWID).

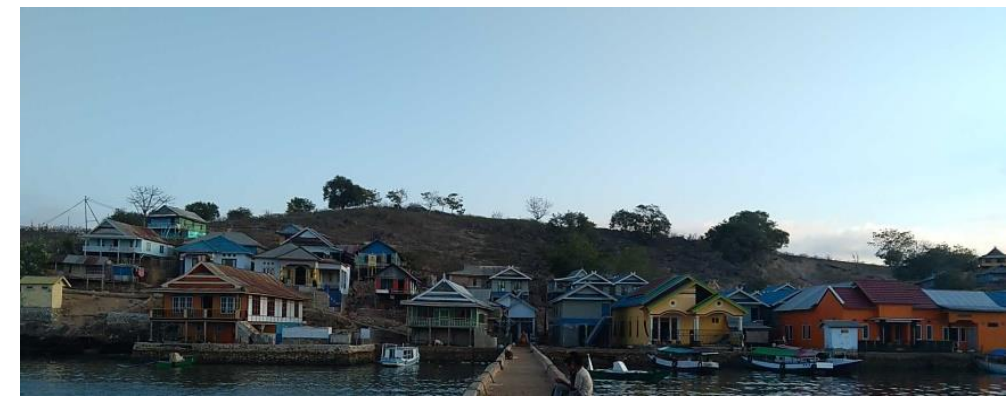

Figure 2. The residential landscape of Bajo Tengah hamlet

Source: Aziz Ali Haerulloh, 2018.

A waterfront city's concept is not optimal due to the low level of public awareness and understanding (Mustika, 2017). There is a paradigm in society regarding "the sea can still be considered to manage waste" (Purba, 2017).

Another cause of the not optimal waterfront city concept is the limited access to collect, dispose, and process waste. Bajo Pulau is a village in the sub-district of Sape, which is geographically isolated from the mainland. Restricted accessibility prohibits local people from gathering and disposing of waste to transfer to the Environment and Forestry Office of the Bima District.

Even if some of the people's houses were facing the sea, this still does not change their attitudes. This may also be inspired by the everyday lives of people who are not clean and healthy. For example, people tend to pay more attention to and care for their clean home environment and neglect the cleanliness of the surrounding environment from household waste and livestock manure, such as poultry and goats.

Bajo Pulau's village has a population of at least 452 people whose welfare conditions are up to $10 \%$ lower in the Province of West Nusa Tenggara (BPS Provinsi Nusa Tenggara Barat, 2015). Poverty faced by some people in Bajo Pulau Village is a form of situational or natural poverty caused by reduced regional capacity (marine fish) due to environmental pollution caused by household waste and garbage (Simanjuntak, Tanjung \& Nasution, 2017: 210). Poverty is increasingly noticeable in coastal fishing communities, which typically live in deprivation due to their poor business skills and consumerism in the community (Nurlaili, Witomo, \& Zamroni, 2014).

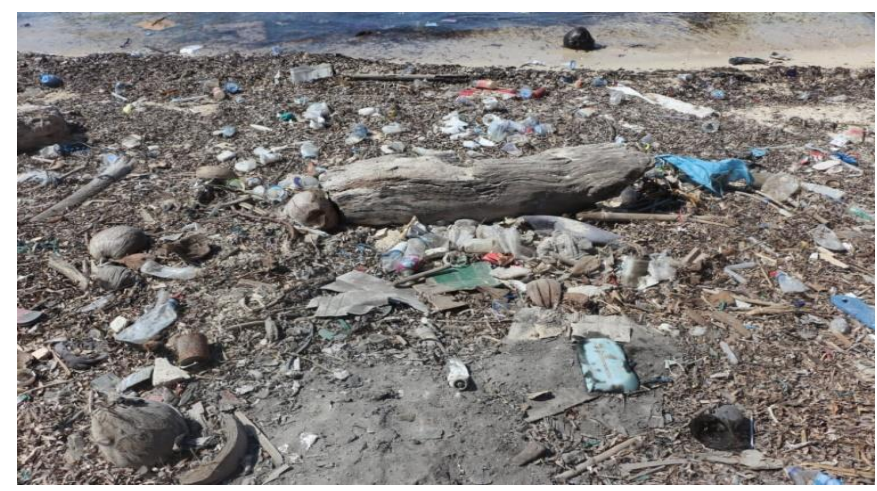

Figure 3. Marine debris (organic and inorganic) on the shores of the Bajo Tengah hamlet Source: Unpad ENJ Documentation Team, 2018. 


\section{Garbage and its impact on land and marine ecosystems in the Village of Bajo Pulau}

The health of Indonesia's seas is of great concern. Indonesia is the second-largest contributor of waste to the sea after China (Purba, 2017). The current waste problem, including marine debris, is a central problem for the world and cannot be handled partially (Coordinating Ministry for Maritime Affairs, 2018). Indonesia directly borders both land and sea with ten countries, so that the waste problem is not only Indonesia's responsibility but regionally and even globally. According to the origin of the waste in the sea comes from fishers, transborder (cross-border), tourists, traders, and the community (household waste) (Purba, 2017). The debris in the sea knows no national, cultural, legal, or ideological boundaries..

The port of Sape in Bima's district is the gateway to East Nusa Tenggara's Province as a province with various national tourist destinations, including Komodo Island, Padar Island, Labuhan Bajo, and others. The Sape Strait is an important connecting route and is quite busy with maritime traffic, tourism, and logistics vessels. However, besides that, we can see a phenomenon of marine debris that floats up to tens or even hundreds of meters in length, as evidence of human behavior patterns that do not pay attention to and take proper care of the environment. Apart from the ocean's garbage, much rubbish is found along the shoreline or near the jetty in Bajo Pulau Village and the western, central, and Pasir Putih hamlets.

"If you look at the constellation of Indonesia as an archipelago and following the flow of the world, waste in the sea comes from two sources. First, waste originating from human activities that flow directly into the sea or flow through rivers. Second, waste from other countries diverted by world currents and trapped in Indonesian waters "(Purba, 2017).

Garbage spread around the Port of Sape and the Pier in Bajo Pulau Village usually comes from household waste in residential areas. This needs to be expected, let alone the bad behaviors repeatedly maintained, becoming a normal culture in society. Here are several preventive measures that can be taken. First of all, educating the youth. Second, increase awareness among policymakers. Third, cross-sectoral collaboration (Penta helix) and fourth, the mission of minimizing plastic waste by reducing the production and usage of single-use plastics (Burhanuddin, 2017). There are various things affected by plastic waste in the ocean - first, the interruption of tourist operations along the coast. Second, life existence and the recovery of millions of aquatic life are at risk, and thirdly, more than three fish caught by fishermen have been found to eat plastics or microplastics (Burhanuddin, 2017). Of course, all of this will reduce the tourist area's original revenue, reduce the level of community wellbeing, and harm the marine environment. The influence is not just short-term but also long-term.

According to (Burhanuddin, 2017), five pillars must be preserved by all Indonesian people in reducing plastic waste in the ocean.: 1. Increased habit change, 2. Reduced soil leakage, 3. Reduced underwater leakage, 4. Industrial markets, and 5. Research and Growth. Research and Development. This is followed by five strategies of the National Action Plan, including the cooperation between local and regional governments, Central Government, Foreign (between countries or regional organizations, such as ASEAN), Industrial markets, and Research development.

The Government of Indonesia 2014-2019, under the leadership of President Joko Widodo and Vice President Jusuf Kalla, declared Nawacita. One of the points to be sought is number two, "Building Indonesia from the periphery by strengthening regions and villages within the framework of a unitary state" (Kominfo, 2015). However, the reality that exists and can be seen in the Bajo Pulau Village shows that the Government is still quite overwhelmed in developing rural areas, such as the Bajo Pulau Village, adjacent to 
the NTT Province as the nation's leading tourist destination. However, Bajo Pulau Village's reality shows that the Government is still quite overwhelmed in developing rural areas as the nation's leading tourist destination.

"Technically, our important role is not to manage the oceans themselves but to manage the people who manage nature. At the moment, ocean garbage trapping technology has been implemented using a different method. However, if this method were not accompanied by human awareness, it would be a constant problem. ... It is not funny if we are a maritime country, but at the same time it is also called a trash country" (Purba,2016)

\section{Bulk store based on the concept of production-consumption cooperative}

The low-waste shop concept is an adaptation of several overseas shops that apply the zero waste concept (generally referred to as bulk). This shop sells a wide variety of products with an eye on environmentally friendly products that eliminate single-use packaging and is usually used to pack sale items. Since different goods sold do not use packaging, buyers must supply their containers/places. Based on field analysis results, this concept is by the community's needs in Bajo Pulau Village. This concept can also reduce household waste, which is generally in packaging for food, beverages, and other daily consumption items such as detergents, shampoo, and soap. This concept also contributes to increasing public awareness of the importance of stopping single-use items that can damage marine ecosystems because they are difficult to decompose. Besides, this concept impacts people's lifestyles to be cleaner, more economical, and healthier.

This research combines the concept of a minimally-waste shop with a cooperative business entity. Choosing a cooperative work system is that cooperative is a business organization of a self-help nature. As a people's economic institution, cooperatives are a non-capitalist economic structure since they are managed by mutual and self-sustaining public funds (Munif, 2017).

A low-waste shop with a production-consumption cooperative system will increase the Bajo Pulau Village community's participation in protecting the environment and entrepreneurship (selling a variety of products made to low-waste shops). Village-level cooperatives have a more significant inclusive position as they seek to improve members' wellbeing (Kuntowijoyo, 2018: 93). Apart from being a member of the minimum waste shop cooperative, the collective also serves as a manufacturer, dealer, and customer. This method can be called a circular economy since it can be assured that the process of production, distribution, and use does not leave any waste at all if there is a minimal amount of waste.

In line with the Government's pledge to minimize plastic waste in the ocean by reducing-reuse-recycles by up to $70 \%$ by 2025 (Burhanuddin, 2017), the theory of a minimum waste shop combined with a production-consumption cooperative work system would accelerate the achievement of the Government's targets. The community's transformation supports this into a 'learning community organization' and promotes responsible community understanding (Joesoef, 2014: 182). This significant move can be started by applying this concept in the Bajo Pulau Village as a pilot to be tested, optimized, and implemented in all small island areas of Indonesia.

The aim of collaborating with the concept of bulk stores in production-consumption cooperatives is to create a form of economic independence for the community of Bajo Pulau Village, which seeks to obtain a much larger and even higher income while retaining the ecological capacity to balance and conserve the environment. If people's consumption needs can be met by a bulk store located in Bajo Pula Village, the effect will be much better. It will break away from the structure that makes a community of people dependent because there is no economic independence. 
Independence in the economic sector can be done because the structure is 'made up from members, by members, and for members.' Regardless of the Indonesian economy's status, the bulk store cooperative can still provide services to the community as long as it requires it as a business organization that meets the community's diverse needs in Bajo Pulau Village.

It is not impossible to develop it if the bulk store cooperative in Bajo Pulau Village can expand its consumers' reach to Sape District in the next ten years. Of course, to reach this stage, there is a need for cooperative management of a low-waste store that is strong in the dynamic era. Local communities' empowerment in terms of educated human resources (HR) needs to be improved to perform management, promotion, finance, and logistics functions. The requirements to become a cooperative manager must be followed by a gradual and continuous coaching process to ensure proven capabilities.

\section{CONCLUSIONS AND RECOMMENDATIONS}

\section{Conclusions}

Bajo Pulau Village's geographical location, which is separated from the mainland (Pulau Sumbawa Besar), causes the community to find it difficult to carry out independent waste management. Besides, the low level of public education also affects the awareness of protecting the environment sustainably. The culture of consumerism in Bajo Pulau and their vigorous daily activities also affects household waste production.

A low-waste shop with a production-consumption cooperative system can improve people's welfare while reducing dependence on various basic needs from outside. Simultaneously, the concept of a minimally-waste shop can also empower the potential of the local community. A bulk store will be more practical in various small inhabited islands to prevent the marine environment's direct pollution, threatening life's survival under the sea.

\section{Recommendation}

The application of the concept of a minimally-waste shop with a productionconsumption cooperative system requires the support of public policies both through regional regulations and the Decree of the Governor of West Nusa Tenggara Province. Besides, the central/local government is also expected to facilitate various collaborations with external parties to improve the community's daily needs that cannot be fulfilled by the various products produced by members of the minimally waste shop cooperative.

\section{REFERENCES}

Annisa, D.N. (2016). Pengendalian Pemanfaatan Ruang di Kawasan Tepian Air (Waterfront) Kota Bulukumba Kabupaten Bulukumba. Jurnal Perencanaan Wilayah \& Kota, 5 (1), 40-51.

Badan Pusat Statistik. (2016). Statistik Sumber Daya Laut dan Pesisir. Jakarta: Badan Pusat Statistik.

Bahagijo, M. (2019). Bulk Store: Konsep Toko Minim Sampah yang Mulai Mendunia. Available at: https://waste4change.com/bulk-store-a-less-waste-store-that-isgaining-popularity-worldwide/2/

Baskara, B. (2011). Manifestasi Identitas Islam Suku Bajo dalam Naskah Lontarak Assalenna Bajo. Jurnal Kawistara, 1 (1), 15-27.

BPS Provinsi Nusa Tenggara Barat. (2015). Jumlah Individu dengan Kondisi Kesejahteraan sampai dengan 10 Terendah Menurut Desa di Provinsi Nusa Tenggara Barat. Available at: https://ntb.bps.go.id/statictable/2016/12/15/164/ 
jumlah-individu-dengan-kondisi-kesejahteraan-sampai-dengan-10-terendahmenurut-desa-di-provinsi-nusa-tenggara-barat-2015.html.

Burhanuddin, S. (2017). Marine Plastic Debris Management In Indonesia. Paper presented in the African Marine Waste Conference: Port Elizabeth.

Cozar, A., Echevarria, F., Gonzales-Gordillo, J. I., Irigioen, X., Ubeda, B., HernandezLeon, S., Palma, A. T., Navarro, S., de-Lomas, J. G., Ruiz, A., de-Puelles, M. L. F., \& Duarte, C. M. (2014). Plastic Debris In The Open Ocean. Proceedings of the National Academy of Sciences, 111(28), 10239-10244. https://doi.org/10.1073/pnas.1314705111.

Efendy, M. (2009). Pengelolaan Wilayah Pesisir secara Terpadu: Solusi Pemanfaatan Ruang, Pemanfaatan Sumber Daya dan Pemanfaatan Kapasitas Asimilasi Wilayah Pesisir yang Optimal dan Berkelanjutan. Jurnal Kelautan, 2 (1), 82-86.

Ekspedisi Nusantara Jaya Universitas Padjadjaran. (2018). Laporan Kuliah Kerja Nyata di Desa Bajo Pulau. Jatinangor: Ekspedisi Nusantara Jaya Universitas Padjadjaran.

Greenpeace. (t.t.) Laut Indonesia Dalam Krisis. Jakarta: Greenpeace Southeast Asia.

Handiani, D. N., Darmawan, S., Heriati, A., \& Aditya, Y. D. (2019). Kajian Kerentanan Pesisir terhadap Kenaikan Muka Air Laut di Kabupaten Subang, Jawa Barat. Jurnal Kelautan Nasional, 14 (3), 145-154.

Handoyo, E., Astuti, T. M. P., Iswari, R., Alimi, Y., \& Mustofa, M. S. (2015). Studi Masyarakat Indonesia. Yogyakarta : Ombak.

Hasan, R. (2018). Konsumerisme dan Falsafah Hidup Masyarakat Indonesia. Available at: $\quad$ https://geotimes.co.id/opini/konsumerisme-pergeseran-falsafah-hidupmasyarakat-indonesia/.

Joesoef, D. (2014). Studi Strategi. Kompas: Jakarta.

Kementerian Koordinator Bidang Kemaritiman. (2018). Hotspot Sampah Laut Indonesia. Jakarta : Kementerian Koordinator Bidang Kemaritiman.

Kementerian Koordinator Bidang Kemaritiman. (2018). Melawan Boikot Uni Eropa atas Sawit. Jakarta : Kementerian Koordinator Bidang Kemaritiman.

Kuntowijoyo. (2018). Demokrasi \& Budaya Birokrasi. Yogyakarta : IRCiSoD.

Kurais. (2016). Islamisasi Suku Bajo di Bima. Gowa : UIN Alauddin Makassar.

Kominfo. (2015). Jadikan Indonesia Mandiri, Berkepribadian, dan Berdaulat. Available at: https://kominfo.go.id/index.php/content/detail/5629/NAWACITA\%3A+9+ Program+Perubahan+Untuk+Indonesia/0/infografis .

Magdoff, F. \& Foster, J. B. (2018). Lingkungan Hidup dan Kapitalisme. Tangerang Selatan: Marjin Kiri.

Marlia. (2012). Pintar Saja Tidak Cukup, tapi Harus Miliki Nilai-nilai Perilaku yang Baik. Available at: http://www.unpad.ac.id/profil/prof-dr-juke-roosjati-siregar-mpd-pintar-saja-tidak-cukup-tapi-harus-miliki-nilai-nilai-perilaku-yang-baik-2/.

Maurilla Imron. (2019, July 9). Online interview (via e-mail).

Maxmanroe.com. (2019). Pengertian Budaya : Arti, Unsur-unsur, Wujud, dan Faktorfaktor Budaya. Available at: https://www.maxmanroe.com/vid/umum/pengertianbudaya.html.

Mulyono, F. (2010). Mengembangkan Koperasi sebagai Pemberdaya Ekonomi Rakyat Indonesia. Jurnal Administrasi Bisnis, 6 (1), 1-21.

Munandar, M.W.A. (2013). Evaluasi Konsep Design Banten Waterfront City Kecamatan Kasemen. Jurnal Planesa, 4 (2), 63-68.

Munif, J. A. (2017). Koperasi dalam masyarakat konsumsi. Available at: https://beritagar.id/artikel-amp/telatah/koperasi-di-masyarakat-konsumsi. 
Mustika, R. (2017). Dampak Degradasi Lingkungan Pesisir terhadap Kondisi Ekonomi Nelayan : Studi Kasus Desa Takisung, Desa Kuala Tambangan, Desa Tabanio. Jurnal Dinamika Maritim, 6 (1), 28-34.

Mustikasari, E., Ramadhan, M., Amry, S. N., Heriati, A., Kadarwati, U. R., Yulius, Prihantono, J., \& Pryambodo, D. G. (2019). Analisis Karakteristik Dimensi Ekologi Pulau-Pulau Kecil Kabupaten Nunukan, Kalimantan Utara. Jurnal Kelautan Nasional, 14 (1), 47-57.

Nasikun. (2015). Sistem Sosial Indonesia. Yogyakarta : Ombak.

Noer, D. (2015). Mohammad Hatta. Jakarta: Kompas.

Nopiana, M., Yulianda, F., Sulistiono., \& Fahrudin, A. (2020). Coastal rehabilitation through the implementation of government policy: Case study in Karawang Regency, West Java, Indonesia. Jurnal Perspektif Pembiayaan dan Pembangunan Daerah, 7 (4), 359-374.

Nurlaili, Witomo, C. M., Zamroni, A. (2014). Potensi dan Permasalahan Sosial Ekonomi Masyarakat Perikanan Kabupaten Lombok Timur dalam Mendukung Industrialisasi. Buletin Risek Sosek Kelautan dan Perikanan, 9 (2), 41-48.

Petungsewu Wildlife Education Center (P-WEC). Hindari Budaya Nyampah. Available at: https://www.p-wec.org/id/go-green/hindari-budaya-nyampah.

Pramudianto, A. (2016). Dari Kyoto Protocol 1997 hingga Paris Agreement 2015: Dinamika Diplomasi Perubahan Iklim Global dan ASEAN menuju 2020. Jurnal Global, 18 (1), 76-94.

Purba, N. P. (2016). Sampah Laut, Ironi di Negara Maritim. Available at: http://maritimenews.com/sampah-laut-ironi-negara-maritim/.

Purba, N. P. (2017). Status Sampah Laut di Indonesia. Available at: http://indosmarin.com/status-sampah-laut-indonesia/.

Purba, N.P., Faizal, I., Pangestu, I. F. (2017). Marine Debris Pencapaian dan Tantangan di Masa Depan. Paper presented at IORA Financing Blue Economy, Bandung.

Riyanto, G. (2018). Asal Usul Kebudayaan. Malang : Beranda.

Rohmad, Z. (2016). Sosiologi Pembangunan. Yogyakarta : Ombak.

Simanjuntak, B. A., Tanjung, F., Nasution, R. (2017). Sejarah Pariwisata. Jakarta: Yayasan Pustaka Obor Indonesia.

Sudirman. (2018, Juli 27). Private interview.

Sulipan. (t.t). Penelitian Deskriptif Analitis. Available at: https://www.academia.edu/ 7215999/Penelitian_Deskriptif_Analitis.

Yudhanto, Y. (2018). Information Technology Business Start-Up. Jakarta: Elex Media Komputindo.

Zuhdi, S. (2006). Laut, Sungai, dan Perkembangan Peradaban. Konferensi Nasional Sejarah VIII Jakarta, 14-16 November 2006, 1-13.

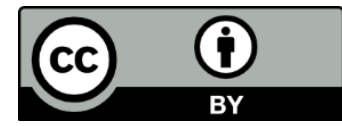

(C) 2020 by the authors. Licensee JPPD, Indonesia. This article is an open-access article distributed under the terms and conditions of the Creative Commons Attribution (CC BY) license (http://creativecommons.org/licenses/by/4.0/). 